\title{
The Cytochromes of Thermoplasma acidophilum
}

\author{
By REINHARD HOLLÄNDER \\ Hygiene-Institut der Philipps-Universität, Marburg, Federal Republic of Germany
}

(Received 25 April 1978)

\section{INTRODUCTION}

Respiratory chain systems containing bound dehydrogenases, flavoproteins, lipoquinones and various cytochromes are common in cell wall-synthesizing bacteria and their L-forms. With the mycoplasmas and related organisms, the determination of respiratory chain components which are presumably present in small amounts has often had to compete with contaminating constituents from the highly complex media. This is probably the reason for the equivocal reports so far presented on the cytochromes of the mycoplasmas (Van Demark, 1969; Van Demark \& Smith, 1964). Members of the Acholeplasma, Mycoplasma and Spiroplasma group contain very small amounts of menaquinones when grown in peptone media supplemented with horse serum, but these probably have no respiratory function (Holländer et al., 1977). However, Thermoplasma acidophilum synthesizes menaquinone-7 in amounts similar to those of respiring bacteria (Langworthy et al., 1972; Holländer et al., 1977) and also $c$-type cytochromes (Belly et al., 1973). This communication reports the occurrence of additional cytochromes in two strains of T. acidophilum.

\section{METHODS}

The strains of $T$. acidophilum, 122-1 $\mathrm{B} 2$ and $112-1 \mathrm{~B} 3$, were grown in a mineral salt medium containing $0.1 \%(\mathrm{w} / \mathrm{v})$ yeast extract and $1 \%(\mathrm{w} / \mathrm{v})$ glucose (Christiansen et al., 1975). 'Aerobic' cultures were grown in Fernbach flasks (no. 20511 ; Schott \& Gen, Mainz, F.R.G.) containing $500 \mathrm{ml}$ medium and aerated by shaking in a rotary shaker at $200 \mathrm{rev}$. $\mathrm{min}^{-1}$. Oxygen-limited cultures were grown statically in Fernbach flasks filled with 21 medium. After about $72 \mathrm{~h}$ incubation at $57^{\circ} \mathrm{C}$, cells, then in the early stationary phase of growth, were harvested by centrifuging $\left(11000 \mathrm{~g}, 4{ }^{\circ} \mathrm{C}\right)$ and washed twice in $0 \cdot 1 \mathrm{M}$-Tris $/ \mathrm{HCl}$ buffer, $\mathrm{pH} 7 \cdot 2$.

Cytochromes were determined by difference spectroscopy of turbid suspensions of untreated cells at liquid nitrogen temperature $\left(-196^{\circ} \mathrm{C}\right)$ with $0.5 \mathrm{M}$-sucrose in the sample (optical path length $0.1 \mathrm{~cm}$; band width $1.65 \mathrm{~nm}$ ) (von Jagow et al., 1973). The characteristic spectral properties of $d\left(a_{2}\right), b$ - and $c$-type cytochromes were recognized by the difference spectrum of $\mathrm{Na}_{2} \mathrm{~S}_{2} \mathrm{O}_{4}$-reduced minus $\mathrm{H}_{2} \mathrm{O}_{2}$-oxidized samples from 390 to $650 \mathrm{~nm}$. Cytochrome $o$ was detected by the difference spectrum of $\mathrm{Na}_{2} \mathrm{~S}_{2} \mathrm{O}_{4} /$ CO-reduced minus $\mathrm{Na}_{2} \mathrm{~S}_{2} \mathrm{O}_{4}$ reduced samples. The spectra were identified according to Bartsch (1968) and Smith (1968).

\section{RESULTS AND DISCUSSION}

The difference spectrum (reduced minus oxidized) of strain 122-183 grown aerobically showed alpha-peaks at 554 and $619 \mathrm{~nm}$ with shoulders at 559 and $549 \mathrm{~nm}$, beta-peaks at 534 and $526 \mathrm{~nm}$ and a gamma-peak at 424 with a shoulder at $434 \mathrm{~nm}$ (Fig. $1 a$ ). A similar spectrum was obtained with cells of strain 122-1в2 (not shown) except that the $549 \mathrm{~nm}$ shoulder was not so pronounced. This might be due to slight differences in culture conditions since the relatively long incubation time made it difficult to reproduce the aeration conditions exactly.

By examining comparable amounts of thermoplasma protein, the cytochrome contents under different culture conditions could be compared. When strain 122-1 33 was grown in oxygen-limited conditions, the $c$-type cytochrome content was decreased especially at 555 $\mathrm{nm}$ and the shoulders at 549 and $560 \mathrm{~nm}$ were more pronounced (Fig. $1 b$ ). The shift of the 


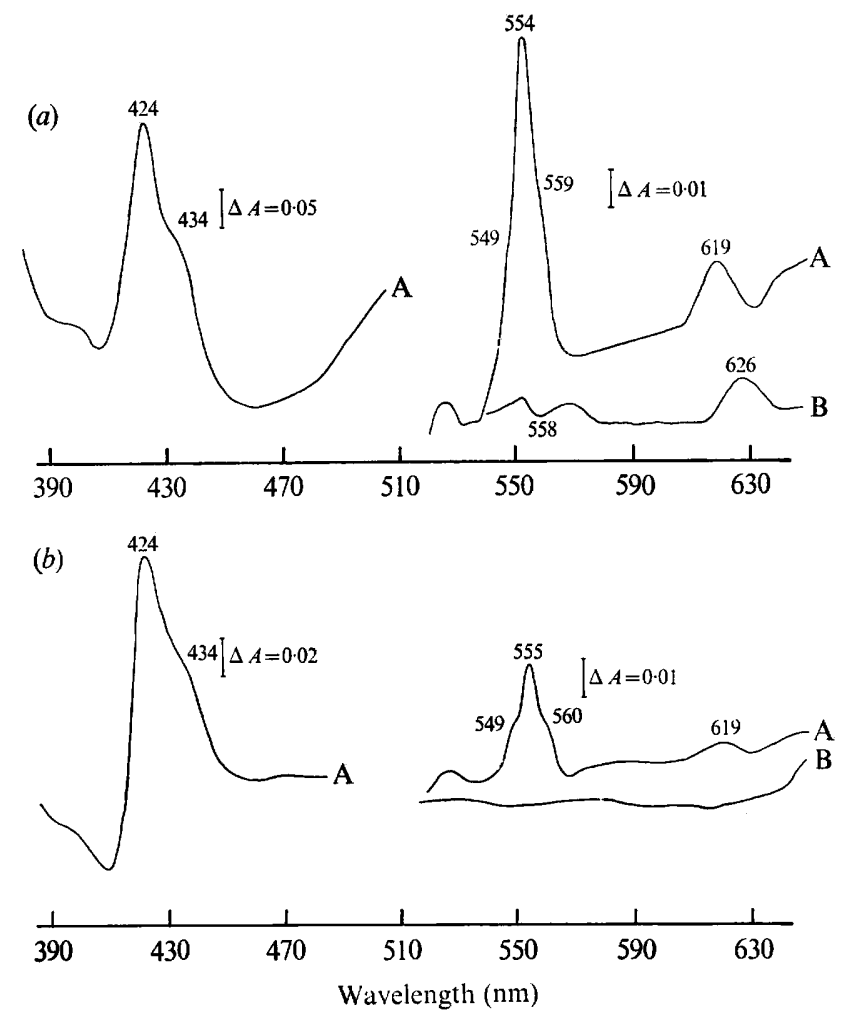

Fig. 1. Cytochrome difference spectra at $-196^{\circ} \mathrm{C}$ of Thermoplasma acidophilum strain 122-183: (a) cells grown aerobically (optical path length $0.1 \mathrm{~cm} ; 12 \mathrm{mg}$ protein $\mathrm{ml}^{-1}$ ); (b) cells grown in oxygen-limited conditions (optical path length $0.1 \mathrm{~cm} ; 10 \mathrm{mg}$ protein $\mathrm{ml}^{-1}$ ). A: $\mathrm{Na}_{2} \mathrm{~S}_{2} \mathrm{O}_{4}$-reduced minus $\mathrm{H}_{2} \mathrm{O}_{2}$-oxidized. B: $\mathrm{Na}_{2} \mathrm{~S}_{2} \mathrm{O}_{4} /$ CO-reduced minus $\mathrm{Na}_{2} \mathrm{~S}_{2} \mathrm{O}_{4}$-reduced.

peak at $554 \mathrm{~nm}$ and the shoulder at $559 \mathrm{~nm}$ by $1 \mathrm{~nm}$ to longer wavelength, compared with aerated cultures, might be due to the relative increase of the $b$-type cytochrome and the decrease in the amount of the $c$-type cytochromes. Strain 122-1B2 exhibited essentially the same cytochromes. In both strains grown under oxygen-limited conditions, the peaks at $619 \mathrm{~nm}$ indicating the cytochrome oxidase $d\left(a_{2}\right)$ were not so pronounced, corresponding to the diminished function of the oxidases under these conditions. The difference spectra of the CO-treated cells of both strains grown aerobically showed the characteristics of cytochrome $o$ at $558 \mathrm{~nm}$, and a shift of $7 \mathrm{~nm}$ to longer wavelength in the absorption of cytochrome $d\left(a_{2}\right)$; these were not detected with cells grown in oxygen-limited conditions.

The presence of cytochromes, cytochrome oxidases and menaquinones (Langworthy et al., 1972; Belly et al., 1973; Holländer et al., 1977) in amounts similar to those in respiring, cell wall-synthesizing bacteria indicated the presence of intact, oxidative, terminal electron transport systems in the Thermoplasma strains investigated. These properties distinguished the Thermoplasma strains from other members of the class Mollicutes in which quinones and cytochromes in comparable amounts have not been detected (Rodwell \& Rodwell, 1954; Gale et al., 1964; Smith et al., 1963; Holländer et al., 1977). The presence of cytochromes in Mycoplasma arthritidis strain 07 and M. bovis seemed doubtful since cytochrome contamination by medium constituents (Smith, 1955) could not be ruled out. Using equipment of normal sensitivity for difference spectroscopy, we could not detect cytochromes in $M$. arthritidis strain 07 grown in PPLO-broth (Difco) supplemented with $20 \%$ (v/v) horse serum and $1 \%(\mathrm{w} / \mathrm{v})$ yeast extract (Holländer et al., 1977).

Thus, amongst the Mollicutes, $T$. acidophilum appears to be unique in producing cyto- 
chromes and lipoquinones. One might therefore argue that the thermoplasmas are closely related to the L-forms of thermophilic and acidophilic, respiring bacteria.

The author wishes to thank Dr E. A. Freundt, Institute of Medical Microbiology, University of Aarhus, Denmark, for the Thermoplasma strains, Drs M. Klingenberg, A. Kröger and G. von Jagow, Institut für Physiologische Chemie und Physikalische Biochemie, München, F.R.G., for help with the cytochrome determinations, and Dr W. Mannheim, Hygiene-Institut der Philipps-Universität, Marburg, F.R.G., for encouragement and helpful criticism.

\section{REFERENCES}

BARTSCH, R. G. (1968). Bacterial cytochromes. Annual Review of Microbiology 22, 181-200.

Belly, R. T., BoHloOl, B. B. \& BROCK, T. D. (1973). The genus Thermoplasma. Annals of the New York Academy of Sciences 225, 94-107.

Christiansen, C., Freundt, E. A. \& Black, F. T. (1975). Genome size and deoxyribonucleic acid base composition of Thermoplasma acidophilum. International Journal of Systematic Bacteriology 25, 99-101.

Gale, P. H., Erickson, R. E., Page, A. C. \& Folkers, K. (1964). Coenzyme Q. LI. New data on the distribution of coenzyme $Q$ in nature. Archives of Biochemistry and Biophysics 104, 169-172.

Holländer, R., Wolf, G. \& MANNHEIM, W. (1977). Lipoquinones of some bacteria and mycoplasmas, with considerations on their functional significance. Antonie van Leeuwenhoek 43, 177-185.

VON JAGOW, G., Weiss, H. \& KLINGENBERG, M. (1973). Comparison of the respiratory chain of Neurospora crassa wild type and the mi-mutants mi-1 and mi-3. European Journal of Biochemistry 33, 140-157.

Langworthy, T. A., Smith, P. F. \& Mayberry, W. R. (1972). Lipids of Thermoplasma acidophilum. Journal of Bacteriology 112, 1193-1200.
Rodwell, A. W. \& Rodwell, E. S. (1954). The breakdown of carbohydrates by Asterococcus mycoides, the organism of bovine pleuropneumonia. Australian Journal of Biological Sciences 7, 18-30.

Smith, P. F. (1955). Amino acid metabolism by pleuropneumonia-like organisms. I. General catabolism. Journal of Bacteriology 70, 552-556.

SMiTH, L. (1968). The respiratory chain system in bacteria. In Biological Oxidations, pp. 55-122. Edited by T.P. Singer. New York: WileyInterscience.

Smith, S. L., Van Demark, P. J. \& Fabricant, J. (1963). Respiratory pathways in the mycoplasmas. I. Lactate oxidation by Mycoplasma gallisepticum. Journal of Bacteriology 86, 893-897.

VAN Demark, P. J. (1969). Respiratory pathways in the mycoplasmas. In The Mycoplasmatales and the L-phase of Bacteria, pp, 491-501. Edited by L. Hayflick. Amsterdam: North Holland Publishing Co.

Van Demark, P. J. \& Smith, P. F. (1964). Respiratory pathways in the mycoplasmas. II. Pathway of electron transport during oxidation of reduced nicotinamide adenine dinucleotide by Mycoplasma hominis. Journal of Bacteriology 88, 122-129. 